\title{
KEEFEKTIFAN MODEL PERMAINAN BOY-BOYAN TERHADAP HASIL BELAJAR TEMA “DIRIKU” SISWA KELAS I SD
}

\author{
1) Cicilia Clara Devi Anggraini' ${ }^{1}$, 2) Mei Fita Asri Untari
}

1Program Studi PGSD, IKIP PGRI Semarang

Jl. Sidodadi Timur No. 24 Semarang

Email: mei_fita@ymail.com

\begin{abstract}
This research is motivated by the importance of integrated thematic learning curriculum themes and 2013 by using the model of traditional games as learning a fun, active, effective and meaningful for students. There are many students who believe that learning in school was just learning in the classroom rigid and monotonous so that students difficult to understand the concept of the teacher taught the material that causes the results low student learning and learning becomes ineffective. Purpose of this study was to determine the effectiveness of the existing models in the game Boy-Boyan integrated thematic learning on learning outcomes theme of "Me". Based on the analysis of data obtained by the price of hypothesis testing tcount 8078 and amounted to 2,021 t table. Because of tcound $>t$ table or 8,078 $>2,021$ then Ho is rejected or it can be said that the difference in average initial conditions to the final conditions significantly. The conclusions is there is effectivenes of the models Boy-boyan games in integrated thematic learning in learning outcomes theme of "me" grade 1 SDN Pandeanlamper 5 Semarang. Keywords: boy-boyan game model, the result of studying the theme of "me".
\end{abstract}

ABSTRAK

Penelitian ini dilatarbelakangi oleh pentingnya pembelajaran tematik terintegrasi kurikulum 2013 dengan menggunakan tema dan model permainan tradisional sebagai salah satu pembelajaran yang menyenangkan, aktif, efektif dan bermakna bagi siswa. Masih banyak siswa yang beranggapan bahwa pembelajaran di sekolah itu hanya belajar di dalam ruangan kelas yang kaku dan monoton sehingga siswa sukar untuk memahami materi yang diajarkan guru yang menyebabkan hasil belajar rendah dan pembelajaran menjadi tidak efektif. Tujuan dalam penelitian ini adalah untuk mengetahui keefektifan model permainan Boy-Boyan dalam pembelajaran tematik terintegrasi terhadap hasil belajar tema "Diriku". Berdasarkan hasil analisis data penelitian uji hipotesis diperoleh harga thitung sebesar 8.078 dan $t$ tabel sebesar 2.021. Karena thitung $>$ t tabel atau 8.078> 2.021 maka Ho ditolak atau dapat dikatakan bahwa perbedaan rata-rata kondisi awal dengan kondisi akhir signifikan. Kesimpulannya adalah terdapat keefektifan model permainan Boy-Boyan dalam pembelajaran tematik terintegrasi terhadap hasil belajar tema "Diriku" siswa kelas 1 SDN Pandeanlamper 5 Semarang.

Kata Kunci: model permainan boy-boyan, hasil belajar tema "diriku".

PENDAHULUAN Pendidikan merupakan faktor yang sangat penting yang mempengaruhi sikap dan tindakan manusia dalam kehidupan, sehingga tidak heran jika kualitas suatu bangsa identik dengan kualitas pendidikannya. Sebagaimana tercantum dalam Undang-Undang Republik Indonesia Nomor 20 tahun 2003 tentang Sistem Pendidikan Nasional Bab I pasal 1 ayat 1 bahwa pendidikan merupakan "usaha sadar dan terencana untuk mewujudkan suasana belajar dan proses pembelajaran agar siswa secara aktif mengembangkan potensi dirinya untuk memiliki kekuatan spiritual keagamaan, pengendalian diri, kepribadian, kecerdasan, akhlak mulia, serta keterampilan yang diperlukan dirinya, masyarakat, bangsa, dan negara". (Undang-Undang Repulik Indonesia, 2003: 2).

Pembelajaran lebih bermakna jika siswa belajar untuk mengetahui sesuatu, belajar 
melakukan, belajar menjiwai dan belajar bersosialisasi dengan teman, sehingga antar siswa terjadi komunikasi baik kelompok maupun individu. Kemampuan berpikir yang komprehensif secara utuh termasuk dalam pembelajaran bermakna karena siswa dapat belajar memecahkan masalah sebagai latihan membiasakan belajar dengan tingkat kognitif tinggi. Pembelajaran bukan hanya mentransfer pengetahuan ke siswa saja tetapi juga melatih siswa untuk berpikir atau berperan aktif dalam pembelajaran. Pembelajaran erat kaitannya dengan adanya perkembangan kurikulum yang terjadi di Indonesia.

Perkembangan kurikulum merupakan bagian dari strategi untuk mencapai tujuan pendidikan yang telah ditetapkan. Dengan berkembangnya kurikulum 2013, diharapkan terjadi peningkatan dan keseimbangan antara kompetensi sikap (attitude), keterampilan (skill), dan pengetahuan (knowledge). Model pembelajaran yang ditekankan dalam Kurikulum 2013 adalah model pembalajaran tematik terintegrasi. Jadi, pembelajaran tematik adalah pembelajaran terpadu yang menggunakan tema sebagai pemersatu materi yang terdapat di dalam beberapa mata pelajaran dan diberikan dalam satu kali tatap muka (Hidayat, 2013: 147).

Guru kesulitan menerapkan pembelajaran yang efektif dan menyenangkan bagi siswa dan guru kurang memberikan kesempatan kepada siswa untuk aktif memanipulasi benda-benda secara langsung, sehingga sebagian besar siswa sukar dan tidak mudah untuk memahami setiap konsep materi yang diajarkan. Selain itu untuk mengenalkan huruf dan angka siswa hanya disuruh maju menuliskannya di papan tulis tanpa menggunakan model yang bervariasi, sehingga hasil belajar yang didapat juga kurang memuaskan dan siswa cenderung lambat untuk menghafalkannya apalagi untuk menulis, hal ini dikarenakan kurangnya pengetahuan dan kemampuan guru dalam menerapkan modelmodel permainan yang dapat digunakan dalam proses pembelajaran tematik terintegrasi yang menarik bagi siswa sehingga perlu adanya alternatif untuk menyelesaikan masalah ini yaitu menggunakan model permainan yang di dalamnya mengajak siswa untuk bermain sambil belajar, karena siswa akan mudah tertarik untuk tampil dan bersosialisasi dengan temannya.
Selain dari wawancara, peneliti juga mengambil sampel dari penelitian terdahulu mengenai berbagai macam permainan yang diterapkan dalam pembelajaran. Hasil penelitian Kurniati dalam Nur (2013: 89) menunjukkan bahwa "permainan anak tradisional dapat menstimulasi anak dalam mengembangkan kerjasama, membantu anak menyesuaikan diri, saling berinteraksi secara positif, dapat mengkondisikan anak dalam mengontrol diri, mengembangkan sikap empati terhadap teman, menaati aturan, serta menghargai orang lain".

Berdasarkan masalah yang ada pada siswa kelas I SD, maka guru hendaknya menggunakan model permainan Boy-Boyan merupakan alternatif yang tepat untuk mengatasinya karena permainan ini dapat dilakukan di luar kelas agar pembelajaran tidak kaku, monoton, dan siswa tidak merasa bosan sehingga siswa cepat memahami konsep materi yang diajarkan dan cocok untuk mengajarkan siswa memahami materi Pembelajaran 2, 4, dan 5 tema "Diriku" sub tema "Aku dan Teman Baruku" dalam buku Guru Tematik Terpadu Kelas 1 Semester 1 Kurikulum 2013. Siswa akan belajar secara kinestetik untuk menggerakkan anggota badannya dan mengeluarkan ide- ide maupun gagasan dengan cara yang menyenangkan, aktif, kreatif, dan inovatif.

Menurut Sisca (2012: 197-198) mengemukakan bahwa model permainan BoyBoyan adalah permainan tradisional dengan total lima sampai 10 orang. Model permainannya yaitu menyusun lempengan batu, biasanya diambil dari pecahan genting atau porcelen yang berukuran relatif kecil. Bolanya bervariasi, biasanya terbuat dari buntalan kertas yang dilapisi plastik, empuk dan tidak keras, sehingga tidak melukai. Satu orang sebagai penjaga lempengan, yang lainnya kemudian bergantian melempar tumpukan lempengan itu dengan bola sampai roboh semua. Setelah roboh maka penjaga harus mengambil bola dan melemparkannya ke anggota lain yang melempar bola sebelumnya. Yang terkena lemparan bola yang bergantian menjadi penjaga.

Model permainan Boy-Boyan yang ada selama ini hanya menitikberatkan pada penyusunan lempengan batu tanpa dimodifikasi dengan gaya yang berbeda, sehingga perlu adanya variasi baru untuk membuat permainan ini lebih 
diminati siswa. Model permainan Boy-Boyan yang dimodifikasi dan dikembangkan oleh peneliti yaitu tumpukan lempengan batu akan diganti menjadi tumpukan kaleng, setiap kaleng dihias dan diberi tulisan bilangan 1 sampai 99, siswa diminta untuk mengurutkan bilangan 1 sampai 99 berbentuk piramid dari yang terkecil hingga terbesar. Kemudian model permainan ini tidak hanya digunakan untuk mengenalkan siswa materi mengurutkan bilangan saja melainkan untuk pengenalan huruf yaitu mengurutkan huruf abjad dari A sampai $\mathrm{Z}$ dan menyusun kata. Selain itu dalam melakukan permainan, siswa diajak untuk menjalankan dan mematuhi peraturan model permainan BoyBoyan yang dilakukan di sekolah dan bernyanyi lagu anak-anak tentang bilangan dan huruf abjad untuk menghidupkan suasana pembelajaran serta siswa diminta untuk menjalankan dan mematuhi peraturan model permainan BoyBoyan yang dilakukan di sekolah. Sama pentingnya dengan variasi yang dimodifikasi dan dikembangkan oleh peneliti, nilai-nilai karakter juga ditekankan dalam model permainan ini sehingga keefektifan dalam menerapkan model permainan ini sangat bagus untuk mendidik anak agar dapat percaya diri dan mampu bergaul dengan teman.

Keunggulan model permainan Boy-Boyan adalah model permainan ini menggunakan budaya lokal/daerah untuk melestarikan seni dan budaya nasional Indonesia yang mengandung petuah dan nilai-nilai filosofi kepada siswa dalam mematuhi aturan. Selain itu dapat dijadikan sebagai sarana pembelajaran sambil bermain. Pembelajaran tidak hanya kaku dan monoton di dalam kelas sehingga siswa dapat belajar tematik terintegrasi di luar kelas melalui cara menghubungkan permainan tradisional dengan membantu siswa dalam memahami materi mengenal dan mengurutkan bilangan, mengenal dan mengurutkan huruf abjad, menjalankan dan mematuhi peraturan model permainan Boy-Boyan yang dilakukan di sekolah dan bernyanyi lagu anak-anak tentang bilangan dan huruf.

Keunggulan lain dari model permainan ini adalah benda kaleng dan bola yang digunakan dalam permainan ini bersifat konkret, dapat mengatasi batasan ruang dan waktu, dapat mengatasi keterbatasan pengamatan, dapat memperjelas suatu masalah, dan peralatan mudah dijangkau dari bahan bekas dengan harga yang murah, serta mudah digunakan tanpa membutuhkan peralatan khusus. Selain itu, model permainan Boy-Boyan juga dapat memudahkan siswa dalam mengamati, menanya, menalar, mencoba, melakukan, dan mengkomunikasikan yang menekankan proses dan hasil yang optimal terutama pada tema "Diriku".

Berdasarkan alasan-alasan yang sudah dipaparkan di atas merupakan faktor utama yang melatarbelakangi peneliti untuk mengadakan penelitian dan tertarik untuk melakukan penelitian dengan judul "Keefektifan Model Permainan Boy-Boyan dalam Pembelajaran Tematik Terintegrasi Terhadap Hasil Belajar Tema "Diriku" Siswa Kelas 1 SDN Pandeanlamper 5 Semarang".

\section{Hasil Belajar}

Belajar ialah suatu proses usaha yang dilakukan seseorang untuk memperoleh suatu perubahan tingkah laku yang baru secara keseluruhan, sebagai hasil pengalamannya sendiri dalam interaksi dengan lingkungannya (Slameto, 2010: 2). Perubahan tingkah laku dalam proses belajar terjadi akibat interaksi yang dilakukan siswa dengan lingkungannya. Belajar melalui interaksi dengan lingkungannya itu berarti belajar keadaan sekelilingnya melalui simbol-simbol.

Gagne (Slameto, 2010: 14) mengemukakan "belajar menggunakan simbol-simbol yang menyatakan keadaan sekelilingnya, seperti: gambar, huruf, angka, diagram, dan sebagainya". Melalui keadaan sekeliling manusia dapat belajar atau mengalami suatu proses perubahan yaitu perubahan tingkah laku sebagai hasil dari interaksi dengan lingkungannya dalam memenuhi kebutuhan hidupnya. Perubahanperubahan akan nyata dalam aspek tingkah laku.

Hasil belajar pada hakikatnya adalah perubahan tingkah laku, tingkah laku sebagai hasil belajar dalam pengertian yang luas mencakup bidang kognitif, afektif, psikomotorik (Sudjana, 2006: 3). Ranah kognitif termasuk dalam informasi verbal, keterampilan intelektual dan strategi kognitif. Ranah afektif termasuk dalam pola-pola perbuatan atau sikap siswa, 
sedangkan ranah psikomotorik termasuk dalam keterampilan motorik yang dimiliki siswa.

Berdasarkan pendapat ketiga para ahli tersebut dapat disimpulkan bahwa hasil belajar adalah perubahan tingkah laku siswa berdasarkan pengalaman-pengalaman yang dilakukan siswa dalam berinteraksi dengan lingkungan. Hasil belajar juga membutuhkan sebuah penilaian dan hasil dari kita belajar.

Sudjana (2006: 8-9) mengemukakan prinsipprinsip penilaian antara lain yaitu:

1) Dalam menilai hasil belajar hendaknya dirancang sedemikan rupa sehingga jelas abilitas yang harus dinilai, materi penilaian, alat penilaian, dan intrepretasi hasil penilaian.

2) Penilaian hasil belajar hendaknya menjadi bagian integral dari proses belajar mengajar.

3) Agar diperoleh hasil belajar yang objektif dalam pengertian menggambarkan prestasi dan kemampuan siswa sebagaimana adanya, penilaian harus menggunakan berbagai alat penilaian dan sifatnya komperehensif.

4) Penilaian belajar hendaknya diikuti dengan tindak lanjutnya.

Jadi dapat disimpulkan penilaian hasil belajar adalah proses pemberian nilai terhadap hasilhasil belajar yang dicapai siswa dengan kriteria tertentu. Hal ini mengisyratkan bahwa objek yang dinilainya adalah hasil belajar siswa.

Menurut Slameto (2010: 54-69), faktor-faktor yang mempengaruhi belajar banyak jenisnya, tetapi dapat digolongkan menjadi dua golongan saja, yaitu faktor intern dan faktor ekstern. Faktor intern faktor yang ada dalam diri individu yang sedang belajar, sedangkan faktor ektern adalah faktor yang ada di luar individu.

Jadi dapat disimpulkan bahwa faktor-faktor yang mempengaruhi belajar yaitu adanya faktor intern dan ekstern. Faktor intern dalam arti yang datang dari dalam diri siswa dan ekstern yang datang dari luar diri siswa.

Menurut Yunanto dalam Hidayat (2013: 146) "pembelajaran merupakan pendekatan belajar yang memberi ruang kepada anak untuk berperan aktif dalam kegiatan belajar". Tema merupakan alat atau wadah untuk mengedepankan berbagai konsep kepada anak didik secara utuh.
Pembelajaran dengan tema diberikan untuk menyatukan isi kurikulum dalam satu kesatuan yang utuh, memperkaya perbendaharaan bahasa siswa, dan pembelajaran melibatkan beberapa mata pelajaran untuk memberikan pengalaman yang bermakna kepada siswa. Keterpaduan dalam pembelajaran ini dapat dilihat dari aspek proses atau waktu, aspek kurikulum, dan aspek belajar, serta pembelajaran. Jadi, pembelajaran tematik adalah pembelajaran terpadu yang menggunakan tema sebagai pemersatu materi yang terdapat di dalam beberapa mata pelajaran dan diberikan dalam satu kali tatap muka.

\section{Model Permainan Boy-Boyan}

Model permainan Boy-boyan terkenal diberbagai daerah di tanah air dengan nama yang berbeda-beda dengan alat yang berbeda namun pada prinsipnya aturan permainannya sama. Nama lain dari permainan tradisional BoyBoyan ini antara lain yaitu permainan Gebok, Bebenceran, dan Gaprek Kempung.

"Gebok" adalah suara yang biasa ditimbulkan apabila bola karet yang digunakan dalam permainan ini mengenai anggota badan dari pemain, sehingga di daerah Penajam Paser Utara (PPU), permainan ini dikenal dengan nama permainan "Gebok". Permainan "Gebok" sudah sangat lama dikenal di Indonesia. Permainan ini terkenal diberbagai daerah di tanah air dengan nama yang berbeda-beda dengan alat yang berbeda namun pada prinsipnya aturan permainannya sama. Di daerah Sunda misalnya, permainan ini dikenal dengan nama bebencaran. Permainan bebencaran menggunakan tumpukan pecahan genting sebagai targetnya. Bencar artinya terurai atau terpecah, sehingga bebencaran menunjuk pada upaya pemain untuk selalu memencarkan potongan genteng yang semula ditumpuk rapih di atas tanah. Di daerah Sulawesi Selatan permainan ini dikenal dengan nama " boy-boyan" dan menggunakan tumpukan batu yang disusun sebagai targetnya. Sedangkan di daerah Pati Jawa Tengah, permainan ini dikenal dengan nama Gaprek Kempung. Permainan gebok menggunakan bola karet (Bola Tenis) dan beberapa kaleng susu bekas. Permainan ini dapat dimainkan oleh anak laki-laki atau perempuan dan jumlah pemain tidak ditentukan. Permainan ini umumnya dimainkan oleh anak-anak berumur 6 sampai 12 
tahun. Dalam permainan ini tidak diperlukan peralatan khusus, yang dibutuhkan hanya 15 buah buah kaleng susu bekas yang disusun bertingkat dan sebuah bola karet. Permainan ini juga membutuhkan halaman yang cukup luas, biasanya anak-anak menggunakan halaman rumah sebagai tempat bermain. Secara selintas dapat diperoleh gambarkan bahwa permainan ini adalah permainan beregu, dimana dalam satu regu minimal berjumlah 2 orang. Kelompok bermain dibagi menjadi dua yaitu regu penyusun dan regu penjaga. Setiap anggota regu penyusun akan bekerja sama dalam menyusun tumpukan kaleng secara bertingkat sedangkan regu penjaga akan bekerja sama dalam melempar bola (bola akan dinyatakan "mati" apabila terlalu lama berada ditangan salah satu anggota regu penjaga) (Cahyono, 2011).

Berdasarkan pengertian model permainan Boy-Boyan yang memiliki banyak arti sesuai dengan pendapat teori di atas. Maka peneliti mengambil salah satu nama Boy-Boyan dari Sulawei Selatan yaitu model permainan BoyBoyan.

Sisca (2012: 197-198) mengemukakan bahwa model permainan Boy-Boyan adalah permainan tradisional dengan total lima sampai 10 orang. Model permainannya yaitu menyusun lempengan batu, biasanya diambil dari pecahan genting atau porcelen yang berukuran relatif kecil. Bolanya bervariasi, biasanya terbuat dari buntalan kertas yang dilapisi plastik, empuk dan tidak keras, sehingga tidak melukai. Satu orang sebagai penjaga lempengan, yang lainnya kemudian bergantian melempar tumpukan lempengan itu dengan bola sampai roboh semua. Setelah roboh maka penjaga harus mengambil bola dan melemparkannya ke anggota lain yang melempar bola sebelumnya. Yang terkena lemparan bola yang bergantian menjadi penjaga.

Berdasarkan pengertian pendapat para ahli, dapat disimpulkan bahwa konsep model permainan Boy-Boyan yang ada selama ini adalah hanya menitikberatkan pada penyusunan lempengan batu tanpa dimodifikasi dengan gaya yang berbeda, sehingga perlu adanya variasi baru untuk membuat permainan ini lebih diminati siswa. Model permainan Boy-Boyan yang dimodifikasi dan dikembangkan oleh peneliti sesuai dengan Kompetensi Inti dan Kompetensi Dasar mata pelajaran Matematika,
Bahasa Indonesia, PPKn dan SPdB yang sudah dijabarkan di latar belakang dalam Pembelajaran 2, 4, dan 5 tematik terintegrasi buku Guru Tematik Terpadu kelas 1 semester 1 kurikukulum 2013 yaitu tumpukan lempengan batu akan diganti menjadi tumpukan kaleng yang disusun secara piramid, setiap kaleng dihias dan diberi tulisan bilangan 1 sampai 99, siswa diminta untuk mengurutkan bilangan 1 sampai 99 berbentuk piramid dari yang terkecil hingga terbesar atau dari yang terbesar hingga terkecil. Kemudian model permainan ini tidak hanya digunakan untuk mengenalkan siswa bilangan saja melainkan untuk pengenalan huruf dan penyusunan kata. Jadi, kaleng dapat dimodifikasi dan diberi tulisan dari huruf A sampai Z. Selain itu dalam melakukan permainan, siswa diajak untuk menjalankan dan mematuhi peraturan model permainan BoyBoyan yang dilakukan di sekolah dan bernyanyi lagu anak-anak tentang bilangan dan huruf abjad untuk menghidupkan suasana pembelajaran. Sama pentingnya dengan variasi yang dimodifikasi dan dikembangkan oleh peneliti, nilai- nilai karakter juga ditekankan dalam model permainan ini sehingga keefektifan dalam menerapkan model permainan ini sangat bagus untuk mendidik anak agar dapat percaya diri dan mampu bergaul dengan teman.

\section{METODE}

Penelitian ini bertujuan mengkaji: "Apakah ada keefektifan model permainan Boy-Boyan dalam pembelajaran tematik terintegrasi terhadap hasil belajar tema "Diriku" siswa kelas I SDN Pandeanlamper 5 Semarang?". Jenis penelitian yang digunakan dalam penelitian ini adalah eksperimen deskriptif kuantitatif, dalam penelitian deskriptif kuantitatif terdapat masalah yang jelas sebagai bahan penelitian. Penelitian ini menggunakan desain True eksperimental Design dengan bentuk One-Group pretest-posttest Design. Dalam desain ini sampel yang digunakan untuk kelas eksperimen maupun kelas kontrol dipilih secara random dari populasi tertentu. Dalam desain ini kelompok pertama (eksperimen) diberi perlakuan sedangkan kelompok kedua (kontrol) tidak diberi perlakuan. Perlakuan yang dimaksud adalah perlakuan dengan model permainan Boy-Boyan. Tempat penelitian ini 
dilakukan di SDN Pandeanlamper 5 semarang pada bulan Desember 2013.

Populasi dalam penelitian ini adalah siswa kelas I SDN Pandeanlamper 5 Semarang Tahun Pelajaran 2013/2014 yang berjumlah 80 siswa. Populasi yang berjumlah 80 siswa tersebut terdiri dari 39 siswa laki-laki dan 41 siswa perempuan. Sampel dalam penelitian ini adalah siswa kelas 1A SDN Pandeanlamper 5 Semarang Tahun Pelajaran 2013/2014 yang terdiri dari 40 siswa meliputi 19 siswa laki-laki dan 21 siswa perempuan. Pengambilan sampel dalam penelitian ini dilakukan dengan menggunakan teknik probability sampling dengan Simple random sampling untuk menentukan kelas eksperimen dan kelas kontrol dengan cara mengundi kedua kelas tersebut. Penentuan sampel dari populasi yaitu diambil dari 2 kelas secara acak antara kelas 1A dan kelas 1B di SDN Pandeanlamper 5 Semarang. Dari hasil undian diperoleh kelas 1A sebagai kelas eksperimen dan kelas 1B sebagai kelas kontrol. Hal ini dilakukan dengan pertimbangan bahwa siswa yang ada di kelas sampel yang diambil mendapat materi dengan kurikulum yang sama, seluruh siswa duduk pada tingkat kelas yang sama yaitu sama-sama kelas I, dan pembagian kelas tidak ada yang menjadi kelas unggulan. Sedangkan untuk mengambil sampel penelitian terhadap siswa di kelas I tersebut dengan menggunakan teknik nonprobability sampling dengan sampling Purposive sampling.

Kelas eksperimen dan kelas kontrol dilakukan uji normalitas dan uji homogenitas. Uji homogenitas digunakan untuk mengetahui bahwa kedua kelas berangkat dari kemampuan awal yang sama. Pada kelas eksperimen dikenai perlakuan tertentu, kelompok kontrol tidak dikenai perlakuan. Selanjutnya dilakukan pengukuran, baik pada kelompok kontrol maupun kelompok eksperimental. Hasilnya dibandingkan dengan menggunakan uji hipotesis yaitu menggunakan uji t-test.

Uji coba instrumen posttest dilakukan di SDN Pandeanlamper 2 Semarang Soal uji coba menggunakan 40 butir soal pilihan ganda yang kemudian diuji validitas, reliabilitas, tingkat kesukaran dan daya pembeda, dari hasil uji tersebut diperoleh 30 butir soal pilihan ganda yang digunakan untuk soal pretest dan posttest. Variabel bebas dalam penelitian ini yaitu model permainan Boy-Boyan dan variabel terikat yaitu hasil belajar siswa tema "Diriku" sub tema "Aku dan Teman Baruku".

\section{HASIL DAN PEMBAHASAN}

Berdasarkan hasil analisis yang telah dilakukan dengan uji normalitas dan uji homogenitas menunjukkan bahwa kedua sampel berasal dari populasi yang berdistribusi normal dan homogen. Hasil perhitungan uji hipotesis analisis test diperoleh thitung sebesar 8.078 sedangkan tabel dengan db N-1 = 40-1 = 39 (dekat dengan 40) dan taraf signifikan 0,05 sebesar 2.021 (Sugiyono 2010: 371). Karena thitung $>$ ttabel yakni $8.078>2.021$ maka Ho ditolak dan Ha diterima atau dapat dikatakan bahwa perbedaan rata-rata kondisi awal dengan kondisi akhir signifikan artinya ada keefektifan model permainan BoyBoyan dalam pembelajaran tematik terintegrasi sehingga dapat meningkatkan hasil belajar tema "diriku" siswa kelas 1 SDN Pandeanlamper 5 Semarang. Hal ini sependapat dengan Sudjana (2006: 3) yang mengatakan bahwa hasil belajar pada hakikatnya adalah perubahan tingkah laku, tingkah laku sebagai hasil belajar dalam pengertian yang luas mencakup bidang kognitif, afektif, psikomotorik. Artinya dengan diberikannya perlakuan pembelajaran menggunakan model permainan Boy-Boyan hasil belajar siswa mengalami perubahan yaitu hasil belajar siswa menjadi meningkat dari pada pembelajaran tanpa menggunakan model permainan Boy-Boyan.

Selain meningkatkan hasil belajar tema "Diriku" sub tema "Aku dan Teman Baruku", keefektifan model permainan Boy-Boyan juga berdampak pada munculnya nilai-nilai karakter pada siswa. Hal tersebut dapat diketahui dari lembar observasi penilaian 18 nilai-nilai karakter yang dikembangkan dalam model permainan Boy-Boyan. Berdasarkan hasil lembar observasi penilaian nilai rata-rata masing-masing 18 nilai karakter yang dikembangkan dalam model permainan Boy-Boyan pada kelas eksperimen siswa kelas 1A SDN Pandeanlamper 5 Semarang tahun pelajaran 2013/2014 diperoleh nilai karakter yang paling tinggi adalah nilai karakter kerja keras (kerja cerdas) dengan nilai rata-rata sebesar 89,69 berada pada kategori baik sekali. Hal ini dikarenakan dalam model permainan Boy-Boyan siswa harus berusaha sekuat tenaga 
untuk menyusun susunan kaleng berbentuk piramid yang telah rubuh dan menguras tenang serta pikirannnya agar dapat menyusun kaleng tersebut sesuai pengurutan huruf abjad dan bilangan yang benar, maka dari itu nilai karakter kerja keras (kerja cerdas) yang paling dominan dan harus dimiliki setiap siswa agar siswa dapat menang dan mudah memahami konsep materi yang diajarkan. Nilai karakter yang paling rendah adalah nilai karakter demokratis dengan nilai rata-rata sebesar 67,5 berada pada kategori cukup. Hal ini dikarenakan dalam model permainan Boy-Boyan siswa tidak dituntut untuk bersikap bijak dan demokratis, tetapi siswa harus berpikir bagaimana dapat selesai menyusun kaleng dengan cepat tanpa terkena lemparan bola dari regu penjaga. Maka nilai karakter demokratis paling rendah karena nilai karakter ini belum sepenuhnya mempunyai pengaruh besar untuk digunakan dalam melakukan model permainan Boy-Boyan.

\section{SIMPULAN}

Berdasarkan analisis data, hasil penelitian, dan pembahasan, maka pada peneltian ini dapat disimpulkan bahwa bahwa ada keefektifan model permainan Boy-Boyan dalam pembelajaran tematik terintegrasi sehingga dapat meningkatkan hasil belajar tema "diriku" siswa kelas 1 SDN Pandeanlamper 5 Semarang. Hal ini dapat dibuktikan dari nilai rata-rata hasil belajar tema "Diriku" sub tema "Aku dan Teman Baruku" pembelajaran 2, 4, dan 5 , pada kondisi awal 76,1 meningkat menjadi 85,925 dan didukung analisis t-test dimana thitung $>$ tabel yakni $8.078>2.021$ sehingga disimpulkan bahwa perbedaan rata-rata kondisi awal dengan kondisi akhir signifikan.

Selain meningkatkan hasil belajar siswa, model permainan Boy-Boyan juga disertai mampu mengembangkan nilai-nilai karakter yang ada pada diri siswa kelas 1 semester 1 tema "Diriku" sub tema "Aku dan Teman Baruku" pembelajaran 2, 4, dan 5 di SDN Pandeanlamper 5 Semarang pada tahun pelajaran 2013/2014 meliputi karakter religius, jujur, toleransi, disiplin, kerja keras (kerja cerdas), kreatif, mandiri, demokratis, rasa ingin tahu, semangat kebangsaan, cinta tanah air, menghargai prestasi, bersahabat/komunikatif, cinta damai, gemar membaca, peduli lingkungan, peduli sosial, dan tanggung jawab. Nilai karakter yang paling tinggi adalah kerja keras (kerja cerdas) sebesar 89,69 termasuk kategori baik sekali dan nilai karakter yang paling rendah adalah karakter demokratis sebesar 67,5 termasuk kategori cukup.

\section{REFERENSI}

Cahyono, Nuri. (2011). “Penerapan Permainan Tradisional Gebok dalam Mengajarkan Matematika".

http://bagusardisaputro.blogspot.com. (diunduh 12 November 2013).

Hidayat, Sholeh. (2013). Pengembangan Kurikulum Baru. Bandung: Remaja Rosdakarya.

Nur, Haerani. (2013). "Membangun Karakter Anak Melalui Permainan Anak Tradisional". Jurnal Pendidikan Karakter. Volume III No. 1. http://journal.uny.ac.id/. $\quad$ (diunduh 8 November 2013).

Sisca. (2012). Aneka Permainan Outbond Untuk Kecerdasan dan Kebugaran. Yogyakarta : Bintang Cemerlang.

Slameto. (2010). Belajar dan Faktor-faktor yang mempengaruhi. Jakarta: Rineka Cipta.

Sudjana, Nana. (2006). Penilaian Hasil Proses Belajar Mengajar. Bandung: PT Remaja Rosdakarya.

Undang-Undang Republik Indonesia Nomor 20 tahun 2003 tentang Sistem Pendidikan Nasional. 